УДК: $75.052,75.041 .5$

ББК: $85.14,85.103(4) 4$

DOI: $10.18688 /$ aa2111-04-38

\title{
Е. А.Немыкина
}

\section{Имперская идеология в задужбинах Душана Сильного и его вельмож в Македонии ${ }^{1}$}

Масштабное расширение границ и усиление Сербского государства в первой половине - середине XIV в. связано с правлением трёх представителей королевской династии Неманичей - Милутина (1282-1321), Стефана Дечанского (1321-1331) и Душана Сильного (1331-1355), при котором завершился процесс совмещения византийской политической и художественной модели с сербскими социокультурными реалиями, начавшийся ещё при Милутине. Душан, объявивший себя в 1346 г. царём сербов и ромеев, окончательно закрепил на государственном уровне имперскую идеологию, которая начала формироваться уже в милутиновскую эпоху. Политические амбиции сербского правителя Душана породили идею о создании единого греко-сербского государства во главе с сербским владыкой. Душан намеревался сербские территории оставить за своим сыном, королем Урошем V (1355-1371), а греческие земли взять под свое управление. Честолюбивые замыслы требовали новых подходов и решений, в том числе в области искусства, так как храмовое строительство и украшение интерьеров церквей фресковыми росписями являлись одним из важнейших способов демонстрации церковно-государственной идеологии, о чём неоднократно упоминалось в научной литературе [14, p. 23-56; 15, p. 299-316; 16, p. 14-15; 9, с.48-66 и др.], однако полномасштабного исследования этой темы до сих пор нет.

Официально из всех сербских владык на царство был венчан только Стефан Душан Сильный, тем не менее на печатях его деда, короля Милутина, в первой четверти XIV столетия также употребляется царский титул [8, с. 62]. Однако несмотря на целенаправленную переориентацию сербской идеологии с национальной платформы на имперскую, локальная специфика не исчезает полностью ни из архитектуры, ни из живописи. Сербская тематика нередко встраивается в новые условия процесса «византинизации»: происходит не только прямое заимствование, но и адаптация греческих образцов к собственному художественному наследию. Проблематика взаимодействия сербской региональной специфики с византийской архитектурной традицией в последние годы последовательно разрабатывается [6, с. 63-66; 7, с.177-199; и др.], однако в настенной живописи данное направление ещё недостаточно изучено и осмыслено.

Прежде чем перейти к фресковым ансамблям времени Душана, кратко отметим иконографические новшества в памятниках периода правления короля Милутина, рас-

1 Исследование выполнено за счёт гранта Российского научного фонда (проект № 20-18-00294) в филиале ЦНИИП Минстроя России «Научно-исследовательский институт теории и истории архитектуры и градостроительства». 
писанных ведущими греческими мастерами в соответствии с основными принципами Палеологовского искусства. Во-первых, исчезает традиционная для росписей рашских храмов XIII столетия процессия сербских правителей, в трёхчетвертном развороте шествующих по направлению к Христу или Богородице - вместо неё появляется новая композиция «Лоза Неманичей» (самое раннее изображение - в росписях церкви Успения в монастыре Грачаница (1318-1321), созданная по образцу византийского извода родословной Христа «Древо Иесеево» и представляющая собой генеалогическое древо династии Неманичей. Во-вторых, начиная с первой четверти XIV столетия, особую значимость получает двойной портрет главных сербских святителей - Симеона Мироточивого и Саввы I Сербского, которые являются олицетворением византийской идеи единения государства и Церкви. Показательно, что для её визуального воплощения сербы обращаются к образам своих национальных святых. В-третьих, существенные отличия наблюдаются между династическими портретами правителей в рашских памятниках XIII в. и в храмах милутиновского периода: в соответствии с византийской императорской иконографией их позы становятся фронтальными и парадно-репрезентативными, а в качестве посредников между сербскими владыками и Христом выступают не Неманичи, как это было раньше, а общевизантийские святые (чаще всего патроны церкви). Также посредством традиционных византийских иконографических формул акцентируется идея богоизбранности ктитора-правителя, благословляемого Христом и получающего императорские инсигнии из рук летящих с небес ангелов. В-четвёртых, особое внимание уделяется прославлению святых воинов (свв. Георгия, Димитрия, Нестора и др.), что могло быть обусловлено военными успехами Милутина, вследствие которых Сербия значительно расширила свои границы ${ }^{2}$. Таким образом, искусство милутиновского времени, с одной стороны, перенимает византийские художественные традиции, что отвечает задаче прославления нового статуса сербского владыки, ставшего королём сильной державы и зятем византийского императора, а с другой - не отказывается полностью от национальной самоидентичности.

В период правления Душана Сильного все перечисленные выше темы получили дальнейшее развитие. Учитывая тот факт, что Душан присоединил к Сербскому государству обширные новые македонские земли, отвоёванные у Византии (Охрид, Прилеп, Касторья и др.), проблематика художественного оформления церквей в контексте имперской идеологии рассматривается на примерах фресковых ансамблей, находящихся на территории нынешней Северной Македонии.

Особенно востребованной в душановских памятниках оказалась композиция «Лоза Неманичей». Она встречается в росписях притворов Богородичной церкви монастыря Печ (ок. 1333-1335, восточная стена), храма Христа Пантократора монастыря Дечаны (1346-1347, восточная стена южного нефа), в нартексе церкви Успения Богоматери монастыря Матейч (между кон. 1340-х - 1360)ํㅡㄹ в в монастыре Студеница (конец XIV -

2 Более подробный анализ сербской тематики в иконографических программах памятников времени короля Милутина см. [11, с. 89-106].

3 Датировка фресок церкви Успения Богоматери монастыря Матейч варьируется в пределах конца 1340-х -1360 гг. В. Джурич относит росписи к 1356-1360 гг. [4, с. 205]; В. Войводич, С. Марьянович-Душанич, Е. Димитрова датируют фрески периодом между 1348 и 1352 гг. [15, p. 315; 3, p. 266;]. С. Чурчич отмечает, что храм был начат в 1343 г. и закончен вместе с фресками в 1352 г. [17, р.643]. 
начало XV в., восточная стена западной входной башни). Специфическими иконографическими особенностями между перечисленными примерами композиций отличается вариант, представленный в Матейче, так как в данном случае в состав генеалогического древа входит не только род Неманичей, но и представители византийской императорской династии Комнинов и болгарской правящей династии Асенов, родственников супруги Душана - царицы Елены (из-за сильных утрат это только предположение). При Милутине «Лоза Неманичей» демонстрировала, прежде всего, богоизбранность, святородность и легитимность власти Неманичей, а в Матейче эта композиция также выражает идею превращения национального сербского государства в империю и легитимизирует возможность для Душана занять и византийский, и болгарский престолы. Генеалогическое древо Неманичей расположено в северной части западной стены нартекса в пандан своему византийскому прототипу - «Древу Иесееву» в южной части той же стены. Между этими двумя композициями существуют не только структурно-композиционные, но и идейно-смысловые параллели, так как в составе «Лозы» царь Душан воспринимается как предводитель «Нового Израиля», под которым понимается Сербское царство.

Другим наглядным примером симбиоза сербской и византийской тематики в Матейче может служить включение в ряд изображений Вселенских соборов в нартексе сербского «Собора короля Стефана». Ещё одним памятником времени Душана Сильного, в котором объединены местные и Вселенские соборы, является церковь Св. Димитрия в Пече (ок. 1345), где помимо двух Вселенских соборов также изображены «Собор св. Саввы» и «Собор св. Симеона Немани и св. короля Милутина» в своде западной травеи. Такое иконографическое решение демонстрировало равнозначность принятых решений как Вселенскими, так и сербскими соборами и являлось одним из отображений легитимности сербской империи и патриархата [14, p.39]. Отметим, что в более ранних росписях храма Св. Ахиллия в Арилье (ок. 1296) в сцене «Собора св. Симеона» родоначальник династии Стефан Неманя представлен на троне в царском облачении, увенчанный короной-стеммой $[1$, c. 144], тогда как в XIII в. он обычно изображался в монашеском облачении (фрески монастырей Милешево, Сопочаны). В надписи к этой фреске он подписан как король, несмотря на тот факт, что он носил титул великого жупана, а королевское достоинство впервые было присвоено его сыну Стефану, в связи с чем в истории он известен под именем Стефана Первовенчанного.

Также в фресковых ансамблях времени Душана продолжает развиваться появившаяся ещё при Милутине тенденция к изображению правителей в парадных фронтальных позах, характерных для репрезентативного изображения византийских императоров, о чём свидетельствует целый ряд фресковых портретов первого сербского царя (Богородичная (Спаса) церковь в Кучевиште (1332-1337); церковь Божией Матери Каранской (1340-1342); церковь Св. Георгия в Полошском монастыре (1343-1345); храм Христа Пантократора в монастыре Дечаны (1346-1347); церковь Успения Богоматери в монастыре Матейч (между кон. 1340-х - 1360) и др.). Величественную торжественную позу Стефан Душан сохраняет даже в композиции Деисуса в росписях церкви Св. Николая в Люботене ${ }^{4}$, где он с королевой Еленой и сыном Урошем стоит по правую руку

4 И. Джорджевич датирует Деисусную композицию в Люботене 1344-1345 гг. [5, с. 112, с. 145]; В. Джурич -1348 г. [4, с. 180]. 
от Христа, занимая таким образом традиционное место предстоящей Спасителю Богородицы, обычно развёрнутой к Нему вполоборота (Илл. 110). Помимо весьма смелого решения замены образа Богоматери портретными изображениями сербской правящей династии отметим в том числе необычное месторасположение данной композиции, так как из западной части храма, где, как правило, изображались исторические личности, семья Душана оказывается на северной стене наоса рядом с алтарной преградой.

Ещё один пример такого же нестандартного размещения правящих монархов можно увидеть в Матейче, где их портреты находятся на южной стене вблизи дьяконника (Илл. 111). Тот факт, что нартекс здесь не отделён от наоса сплошной стеной и пространство храма можно охватить одним взглядом как единое целое, даёт возможность в полной мере ощутить стремление подчеркнуть значимость ктиторов-правителей, в том числе относительно образов свв. Константина и Елены, рядом с которыми сербские владыки обычно находились в западной части храма. Однако в Матейче происходит отступление от привычной схемы, и свв. Константина и Елена расположены симметрично портретам семьи Душана на южной стене, однако их образы по обыкновению размещены в нартексе, тогда как изображение царской семьи перенесено в наос и вновь непосредственно к алтарной части, занимая таким образом гораздо более почётное место с точки зрения иерархического деления храма на сакральные зоны, чем одни из самых почитаемых общевизантийских святых.

Люботенский Деисус - не единственный пример включения царских портретов в состав религиозных композиций. В южном парекклесии Св. Николая храма Христа Пантократора в монастыре Дечаны семья Душана изображена в составе цикла сцен Акафиста Богородице. В центре композиции, иллюстрирующей 13 кондак («О Всепетая Мати...») песнопения, помещена икона Богоматери Одигитрии. Слева от иконы представлен епископ в полиставрионе, за ним - певцы и монахи, а справа от Богородицы правящая семья: король Стефан Душан в торжественной позе и царском облачении держит в правой руке скипетр, а левую возложил на голову маленького Уроша, также одетого в пурпурный саккос, с короной на голове и со скипетром в руке, царица Елена держит сына за плечо и простирает свою левую руку к иконе Богоматери. Такое размещение сербских правителей указывает на прямую аналогию с византийскими императорами, по традиции константинопольского двора участвовавшими в праздновании, посвящённом Богородице в субботу пятой седмицы Великого Поста, важную роль в котором играла икона Богоматери Одигитрии, представленная на данной фреске. Сцена является одним из свидетельств заимствования обычаев византийского церемониала сербским двором [13, с. 368; 12, с. 53-54].

На примере люботенской композиции кратко обозначим ещё одно из важных изменений в иконографических программах времени Душана - появление наряду с ктиторской композицией и отдельного изображения правителей и их сосуществование в одном и том же храмовом пространстве. В упомянутой выше Деисусной композиции представлены портреты сербского царя и его семьи, а не ктиторов, хотя церковь Св. Николая в Люботене - это аристократическая задужбина, возведённая по заказу некой госпожи Даницы и её сыновей Бойко и Димитра в 1336/1337 гг. [5, с. 145]. Отделение ктиторской композиции от композиции с представителями правящей династии, которые 
составляли единое целое в сербской настенной живописи XIII в. и первой четверти XIV столетия, является своеобразным маркером времени, указывающим на изменения в социополитической и культурной жизни Сербского государства. Если раньше ктиторами храмового строительства и украшения церквей росписями в основном были сами правители, то при Душане появляется вторая мощная сила, с которой приходилось считаться - это занимающие высокое положение при дворе вельможи. Стремясь поднять престиж сербского двора, Душан присваивал им византийские титулы, и аристократическая верхушка активно участвовала не только в политической, но и в художественной жизни государства, возводя задужбины для собственных семей ${ }^{5}$.

В портретах сербских владык времени Душана Сильного, как и в более ранних памятниках короля Милутина, отсутствуют предки-Неманичи в качестве посредников между ныне здравствующим правителем и небесными покровителями. В качестве одного из примеров данной тенденции можно привести композицию в церкви Христа Пантократора в Дечанах: в расположенной над входом в наос сцене сербские короли Стефан Дечанский и Стефан Душан обращаются к Христу Пантократору напрямую. Их склоненные позы, жесты рук, сложенных в молении, а также небольшие масштабы фигур по сравнению с образом Христа отсылают к композициям проскинезиса, весьма характерным для византийской иконографической традиции.

Однако почитание собственных предков при Душане и его сыне Уроше V не исчезает полностью: как и при Милутине, в иконографические программы часто включена т. н. «святая двоица» - родоначальник «святородной династии» сербских правителей Стефан Неманя (св. Симеон Мироточивый) и первый сербский архиепископ св. Савва (храм Христа Пантократора в Дечанах (1346-1347), церковь Св. Архангелов в Лесново (1347-1348); церковь Св. Николая в Псаче (1365-1371); и др.). Присутствие главных национальных сербских святых в храмовых росписях должно было иметь для первого сербского царя особое значение, так как Неманя не только стоял во главе правящей династии, но и основал независимое Сербское государство, а Савва добился автокефалии для сербской Церкви, тогда как сам Душан создал Сербское царство и учредил сербский патриархат.

Образы свв. Симеона и Саввы также играли существенную роль в тех композициях, посредством которых отображался процесс урегулирования отношений между сербской Печской архиепископией, ставшей при Душане патриархатом, и Охридской архиепископией. В частности, на южном фасаде церкви Св. Николая Больничного в Охриде (ок. 1345) наряду с портретами правящей династии представлены св. Симеон Мироточивый, св. Савва Сербский, патрон храма св. Николай и Николай, архиепископ Охридский. Данный групповой портрет мог возникнуть как отклик на достигнутый компромисс между сербскими властями и Охридской архиепископией, согласно которому последняя сохраняла за собой самостоятельность, однако вынуждена была признать сербское владычество.

Симбиоз сербской тематики с местными охридскими традициями отчасти отражают и фрески Григорьевой галереи на втором этаже нартекса собора Св. Софии (ок. 1355)

5 Более подробно о сосуществовании в росписях времени Стефана Душана ктиторской композиции наряду с изображением правителей см. [10, с. 799-808]. 
в Охриде, где на восточной стене над входным проёмом сохранились остатки ктиторской композиции, относительно которой существует предположение, что в её северной части изображены царь Душан с супругой царицей Еленой, а в южной - их сын Урош [2]. Последнего сопровождает особо почитаемый святой св. Климент Охридский, тогда как рядом с царственной четой изображены неизвестный монах, идентифицируемый как св. Симеон Неманя, и св. Савва I Сербский. Таким образом, один из самых почитаемых в македонских и соседних с Охридом славянских землях святых - св. Климент - и представители династии Неманичей объединены здесь в единую композицию [2, с. 328], что является живым откликом на современные политические реалии. Обращение к образам двух этих святых является свидетельством того факта, что амбиции Душана Сильного сделать свое государство настолько мощным и развитым и в политическом, и в культурном аспектах, чтобы оно было способно заменить Византию, однако не упразднило идею «святородной династии» Неманичей, к которой он принадлежал, а следовательно, и национальную составляющую в его имперских идеологических установках.

Идея о греко-славянском единстве, зародившаяся ещё при Милутине и ставшая катализатором для умножения славянских святых (св. Климент, св. Константин Кавасила, св. Иоаким Осоговский, св. Прохор Пчиньский) в иконографических программах, при Душане Сильном закрепила свои позиции. Со времён правления Милутина продолжали использовать греческий язык в подписях к фрескам в противовес устоявшейся традиции XIII в., согласно которой в рашских настенных росписях применялась в основном только кириллица. Как и при Милутине, данное нововведение объяснялось смешанным населением на присоединённых территориях и практикой богослужений в Охридской архиепископии, использовавшей и греческий, и славянский языки.

Поиск новых иконографических решений в условиях изменившихся политических и художественных реалий привёл также к адаптации двух давно существовавших изводов: «Небесная литургия» трансформировалась в композицию «Небесного двора» (церковь Успения в монастыре Трескавац (ок. 1340); церковь монастыря Богоматери Заумской недалеко от Охрида (ок. 1361); церковь Св. Димитрия в Марковом монастыре близ Скопье (1376-1381); церковь Св. Афанасия ту Музаки в Кастории (1385) (Илл. 112)), а традиционный Деисус облачился в царские одеяния и известен под названием «Царского Деисуса». С точки зрения иконографии обе композиции тесно связаны друг с другом, однако их анализ выходит за рамки данной статьи и требует отдельного рассмотрения.

Стремление урегулировать отношения между сербским патриархатом и охридской церковью, а заодно укрепить свои позиции на завоёванных территориях со смешанным греко-славянским населением подталкивают Душана не только к усвоению византийской культурной и политической модели, но и к обращению к определённым национальным традициям, соответствующим честолюбивым планам и политическим амбициям сербского правителя. В иконографических программах памятников это отражается в заимствовании и переосмыслении византийского материала, в появлении новых интерпретаций известных композиций и сюжетов, что представляет богатый материал для изучения локальной специфики в рамках общевизантийских художественных процессов. 


\section{Литература}

1. Војводић Д. Зидно сликарство цркве Светог Ахилије у Ариљу. - Београд: Стубове културе, 2005. $245 \mathrm{c}$.

2. Грозданов Ц. Свети Симеон Немања и свети Сава у сликарској тематици у Македонији (XIV-XVII) // Стефан Немања - Свети Симеон Мироточиви. Историја и предање: међународни научни скуп септембар, 1996 / Уред. J. Калић. - Београд: САНУ, 2000. - С.319-345.

3. Димитрова Е. Манастир Матејче. - Скопьје: Каламус, 2002. - 528 с.

4. Джурич В. Византийские фрески. Средневековая Сербия, Далмация, славянская Македония. - М.: Индрик, 2000. - 592 с.

5. Борђевић И. М. Зидно сликарство српске властеле у доба Немањића. - Београд: Филозофски факултет, 1994. - 309 с.

6. Мальцева С. В. Значение приделов в формировании региональной традиции в сербской средневековой архитектуре // Актуальные проблемы теории и истории искусства. Сб. науч. статей. Вып. 1 / Под ред. С. В. Мальцевой, Е. Ю. Станюкович-Денисовой. - СПб.: НП-Принт, 2011. - С. 63-66.

7. Мальцева С. В. Приделы в сербских храмах XIII - первой половины XIV в. // Византийский временник. — № 71(96). - 2012. - С. 177-199.

8. Мошин В. Повеље краља Милутина - дипломатичка анализа // Историјски часопис. - № 18. 1971. - С. 53-86.

9. Немыкина Е. А. Влияние императорской проблематики на монументальные росписи Сербии XIV в. на примере композиции «Небесный двор» в Успенской церкви монастыря Трескавац // Вестник ПСТГУ. Серия V: «Вопросы истории и теории христианского искусства». - Вып. 4 (24). - 2016. C. 48-66. DOI: $10.15382 /$ sturV201624.48-66

10. Немыкина Е. А. Портреты ктиторов и правителя во фресковых ансамблях времени Душана Сильного // Актуальные проблемы теории и истории искусства: сб. науч. статей. Вып. 10 / Под ред. А. В. Захаровой, С. В. Мальиевой, Е. Ю. Станюкович-Денисовой. - МГУ имени М. В. Ломоносова / СПб.: НППринт, 2020. - C. 799-808. DOI: 10.18688/aа200-7-74

11. Немыкина Е.А. Трансформация идеологии Неманичей в памятниках эпохи Милутина (12821321) на завоеванных македонских территориях // Studia Slavica et Balcanica Petropolitana. - № 1. 2020. - C. 89-106. DOI: 10.21638/spbu19.2020.206 (дата обращения: 01.09.2021)

12. Радојчић С. Портрети српских владара у средњем веку. - Београд: Републички завод за заштиту споменика културе, 1996. - 231 с.

13. Тодић Б., Чанак-Медић М. Манастир Дечани. - Београд: Музеј у Приштини, 2005. - 535 с.

14. Djurić V. J. Lart impérial serbe: marques du statut impérial et traits de prestige // Byzantium and Serbia in the $14^{\text {th }}$ Century. National Hellenic Research Foundation. Institute for Byzantine Research. International Symposium 3 / Ed. E. Papadopoulu, D. Dialety. - Athens, 1996. - P.23-56.

15. Marjanović-Dušanić S., Vojvodić D. The Model of the Empire - The Idea and Image of Authority in Serbia (1299-1371) // Сакрална уметност српских земаља у средњем веку / Ред. Д. Војводић, Д. Поповић. Београд: Службени гласник, 2016. - С. 299-316.

16. Ćurčić S. Gračanica. King Milutin's church and its place in late Byzantine architecture. - University Park and London: Pennsylvania State University Press, 1979. - 159 p.

17. Curčić S. Architecture in the Balkans. - Yale University Press, 2010. - 913 p.

Название статьи. Имперская идеология в задужбинах Душана Сильного и его вельмож в Македонии

Сведения об авторе. Немыкина Елена Александровна — научный сотрудник. Филиал ФГБУ «ЦНИИП Минстроя России» Научно-исследовательский институт теории и истории архитектуры и градостроительства (НИИТИАГ), ул. Душинская, 9, Москва, Российская Федерация, 111024. tsvetynaveter@ gmail.com ORCID: 0000-0001-6458-8534

Аннотация. Статья посвящена особенностям иконографических программ памятников времени правления Стефана Душана Сильного, сформировавшихся под влиянием церковно-политической идеологии и имперских амбиций сербского правителя. Присоединение новых территорий, усиление политических амбиций Сербского государства и стремление сильнейшего в его истории короля Стефана Душана, в 1346 г. объявившего себя царем, видеть свою страну на равных позициях с Византийской 
империей, Сербскую автокефальную Церковь - с Константинопольским патриархатом, а себя самого - с византийским василевсом, выводит на первый план императорскую проблематику для искусства всего региона. Анализ фресковых ансамблей на территории Македонии этого периода является одним из ключевых моментов для более глубокого понимания процессов эволюции средневековой живописи в Сербии и Македонии на том этапе, когда в составе Сербского государства оказываются территории с разной исторической, политической и этнической составляющими.

Ключевые слова: Сербия, Македония, средневековая живопись, Стефан Душан, средневековое искусство, имперская идеология, фрески, иконография

Title. Imperial Ideology Expressed in the Church Architecture of the Tsar Dusan the Mighty and his Nobles in Macedonia ${ }^{6}$

Author. Nemykina, Elena Aleksandrovna - researcher. Scientific Research Institute of Theory and History of Architecture and Urban Planning, branch of the Central Institute for Research and Design of the Ministry of Construction and Housing and Communal Services of the Russian Federation, Dushinskaya ul., 9, 111024 Moscow, Russian Federation. tsvetynaveter@gmail.com ORCID: 0000-0001-6458-8534

Abstract. The article is devoted to the peculiarities of iconographic programs of the fresco cycles during the reign of Stefan Dusan the Mighty, formed under the influence of the political ideology and imperial ambitions of the Serbian ruler. The annexation of new territories, strengthening of the political ambitions of the Serbian state, and desire of the strongest king in history of Serbia, Stephen Dusan, who declared himself a tsar in 1346, to see his country on an equal footing with the Byzantine Empire, the Serbian Autocephalous Church with the Patriarchate of Constantinople, and himself equal with the Byzantine Basileus, brings to the fore the imperial problematic for the art of the entire region. The analysis of the Macedonian fresco ensembles of this period is one of the crucial aspects for a deeper understanding of the evolution of medieval painting in Serbia and Macedonia at the stage when the territories with different historical, political, and ethnic constituents had been included in the Serbian state.

Key words: Serbia, Macedonia, medieval painting, Stefan Dusan, medieval art, imperial ideology, frescoes, iconography

\section{References}

Ćurčić S. Architecture in the Balkans. Yale University Press Publ., 2010. 913 p.

Ćurčić S. Gračanica. King Milutin's Church and Its Place in Late Byzantine Architecture. University Park; London, Pennsylvania State University Press Publ., 1979. 159 p.

Dimitrova E. Manastir Matejche (Matejče Monastery). Skop'e, Kalamus Publ., 2002. 528 p. (in Macedonian).

Djurić V. J. L'art impérial serbe: marques du statut impérial et traits de prestige. Byzantium and Serbia in the $14^{\text {th }}$ Century: International Symposium 3. Athens, National Hellenic Research Foundation, Institute for Byzantine Research Publ., 1996, pp.23-56 (in French).

Đorđevich I. M. Zidno slikarstvo srpske vlastele u doba Nemanjicha (Wall Painting of the Serbian Nobles in the Time of Nemanjić). Belgrade, Filozofski fakultet Publ., 1994. 309 p. (in Serbian).

Đurić V. Vizantiiskie freski. Srednevekovaia Serbiia, Dalmatsiia, slavianskaia Makedoniia (Byzantine Frescoes. Medieval Serbia, Dalmatia, Slavic Macedonia). Moscow, Indrik Publ., 2000. 592 p. (in Russian).

Grozdanov Ts. Saint Simeon Nemanja and Saint Sava in Painting in Macedonia (XIV-XVII). Stefan Nemanja - Sveti Simeon Mirotochivi. Istorija i predanje: medzhunarodni nauchni skup septembar, 1996 (Stefan Nemanja - Saint Simeon the Myrrh-bearer. History and Tradition: International Scientific Conference, September, 1996). Belgrade, SANU Publ., 2000, pp.319-345 (in Serbian).

Maltseva S. V. The Significance of Chapels in the Formation of Regional Tradition in Serbian Medieval Architecture. Maltseva S., Stanyukovich-Denisova E. (eds.). Actual Problems of Theory and History of Art: Collection of Articles, vol. 1. St. Petersburg, NP-Print Publ., 2011, pp. 63-66 (in Russian).

Maltseva S. V. Subsidiary Chapels in Serbian Churches of the $13^{\text {th }}-$ the First Half of the $14^{\text {th }}$ Centuries. Vizantiiskii vremennik, 2012, no. 71 (96), pp.177-199 (in Russian).

6 This research has been completed with the support of the Russian Science Foundation (RSF), project no. 20-18-00294. 
Marjanović-Dušanić S.; Vojvodić D. The Model of the Empire - The Idea and Image of Authority in Serbia (1299-1371). Sakralna umetnost srpskih zemalja u srednjem veku (Sacral Art of the Serbian Llands in the Middle Ages). Belgrade, Sluzhbeni glasnik Publ., 2016, pp. 299-315.

Moshin V. Charters of King Milutin - Diplomatic Analysis. Istorijski chasopis (Historical Journal), 1971, no. 18, pp. 53-86 (in Serbian).

Nemykina E. A. The Influence of the Imperial Topics on the Serbian Monumental Painting of the $14^{\text {th }}$ Century by the Example of the Composition "The Heavenly Court" of the Assumption Church of the Trescavec Monastery. Bulletin of the Orthodox St. Tikhon University for the Humanities, 2016, vol. 4 (24), pp. 48-66 (in Russian).

Nemykina E. A. Portraits of Ktetors and the Ruling Sovereign in Fresco Ensembles of the Time of Dušan the Strong. Zakharova A. V.; Maltseva S. V.; Staniukovich-Denisova E. Iu. (eds.). Actual Problems of Theory and History of Art: Collection of Articles, vol. 10. Moscow, Lomonosov Moscow State University; St. Petersburg, NPPrint Publ., 2020, pp. 799-808 (in Russian). https://doi.org/10.18688/aa200-7-74

Nemykina E. A. Transformation of the Nemanichi's Ideology in the Monuments of the Milutin Era (12821321) in the Conquered Macedonian Territories. Studia Slavica et Balcanica Petropolitana, 2020, no. 1, pp. 89106 (in Russian).

Radojchić S. Portreti srpskikh vladara u srednjem veku (Portraits of Serbian Rulers in the Middle Ages). Belgrade, Republichki zavod za zashtitu spomenika kulture Publ., 1996. 231 p. (in Serbian).

Todić B.; Čanak-Medić M. Manastir Dečani (Dečani Monastery). Belgrade, Muzej u Prishtini Publ., 2005. 535 p. (in Serbian).

Vojvodić D. Zidno slikarstvo tsrkve Svetog Akhilije u Arilju (Wall Paintings of the Church of Saint Achilleos in Arilje). Belgrade, Stubove culture Publ., 2005. 245 p. (in Serbian). 


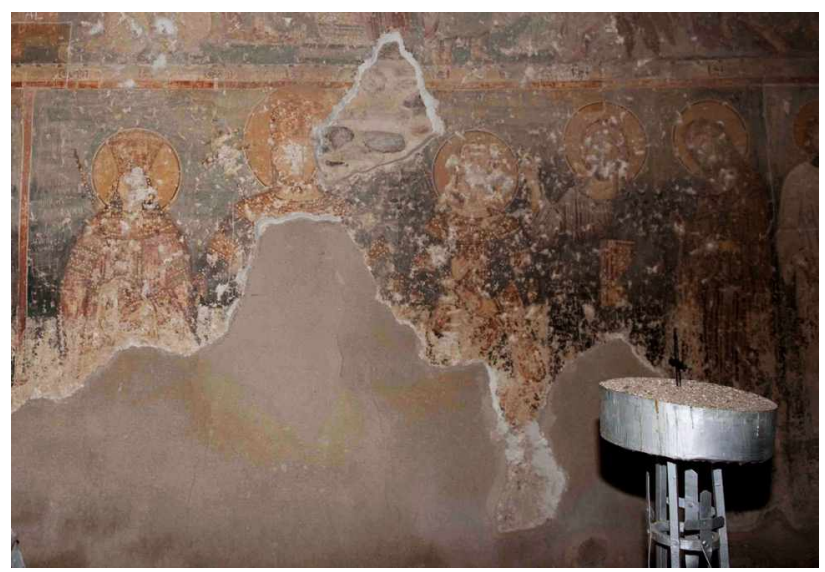

Илл. 110. Стефан Душан Сильный с супругой Еленой и сыном Урошем в составе Деисусной композиции. 1340-е гг. Фреска. Церковь Св. Николая в Люботене, Северная Македония. Фотография С.В. Мальцевой

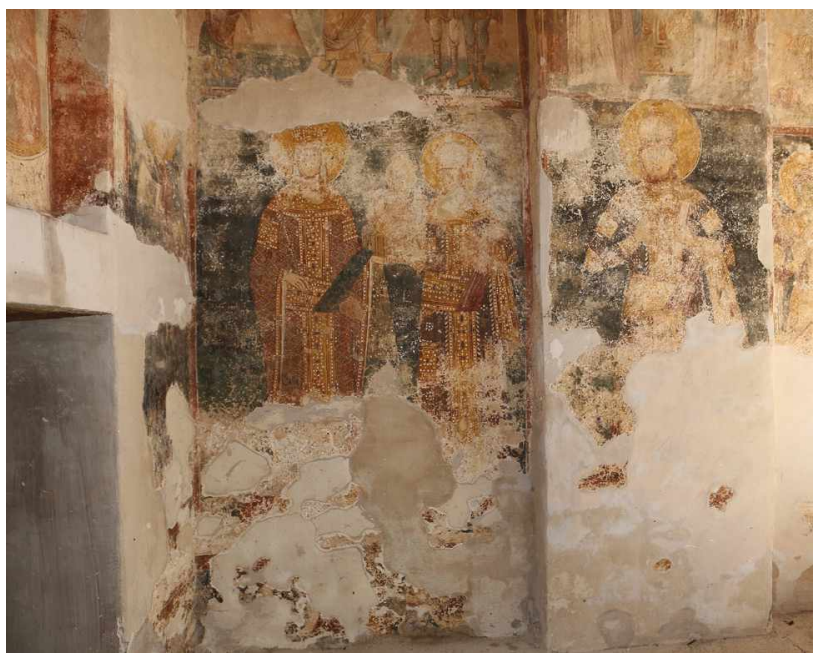

Илл. 111. Стефан Душан Сильный с супругой Еленой и сыном Урошем. 1350-е гг. Фреска. Церковь Успения Богоматери монастыря Матейч, Северная Македония. Фотография Е.А.Немыкиной

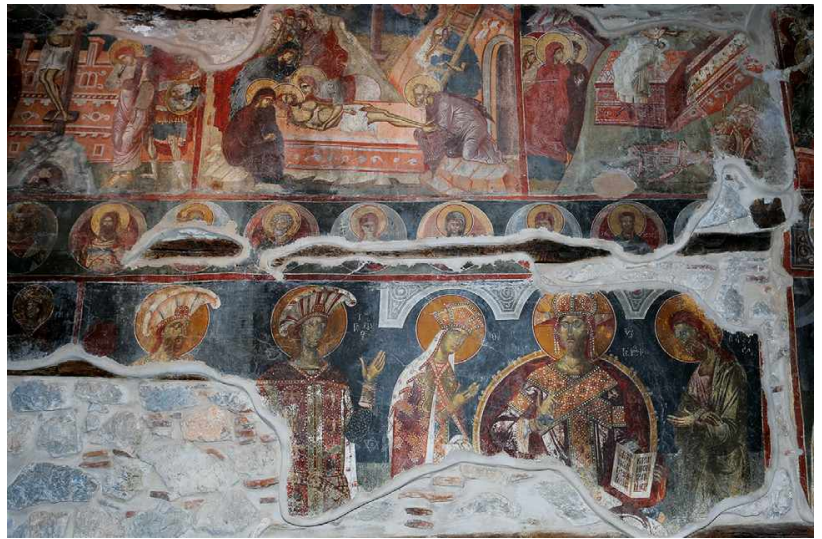

Илл. 112. Небесный двор.

1385 г. Фреска. Церковь Св. Афанасия ту Музаки в Кастории, Греция.

Фотография А.В.Захаровой 